UDC 539.3

DOI https://doi.org/10.32838/TNU-2663-5941/2020.3-2/22

Gomon S.S.

National University of Water and Environmental Engineering

Pilipaka L.M.

National University of Water and Environmental Engineering

\title{
EXPERIMENTAL STUDIES OF THE GLUED WOOD STRENGTH AND DEFORMATION PROPERTIES UNDER THE HARD TEST MODE
}

A detailed review of domestic and foreign scientists works on this issue has been carried out. The modern testing equipment of domestic and foreign production is analyzed. A technique has been developed for experimental studies of glued wood of deciduous (birch, alder, ash) and coniferous (larch, pine, spruce) species with the onetime short-term load along the fibers under the hard test conditions on modern servo-hydraulic testing machines.

For the first time, purposeful experimental studies of glued wood prisms of structural dimensions of all studied wood species with uniaxial short-term load along the fibers were carried out under the hard test mode (by the increase in the movements of the testing machine). Based on the results of experimental studies, complete diagrams of the deformation of coniferous and deciduous species of glued wood from the beginning of loading to their complete destruction, as well as complete diagrams with a limit at the point of ultimate deformations, are constructed. It is proved that glued wood works on ascending and descending branches. Experimentally established the actual work and stress-strain state of glued wood under uniaxial load along the fibers under the hard test mode (by the increase in the displacements of the testing machine plate). The critical deformations of all investigated coniferous and deciduous species of glued wood, as well as the corresponding maximum stresses were established. The initial elastic moduli of glued wood and the transverse moduli of deformation are determined. It has been established that the strength of glued wood of all studied species is on average 15-25\% higher than of solid, and the critical deformations remain almost unchanged.

In the future, it is necessary to develop a methodology for calculating bent and compressed wooden structures, taking into account the full deformation diagram of solid and glued wood.

It is indicated that in the future it is necessary to conduct experimental studies of glued wood elements that will be impregnated with various kinds of chemical elements (monomers or oligomers) in order to strengthen such materials.

Key words: glued wood, strength, deformability, critical deformations, stresses, full deformation diagram.

Problem statement. One of the most promising materials and structures in various industries, in particular in industrial and civil engineering (floors, windows, doors, various components and parts, floors and coatings of buildings, structures, etc.), road construction (bridges, floorings, piles, sleepers, platforms), shipbuilding; the furniture industry, is solid, glued and modified wood of various species and it will remain for many years. Some species of wood, mostly coniferous (pine, spruce, larch, yew, fir), are used in construction in supporting structures of buildings and structures, bridge structures, etc., while others are deciduous (birch, ash, alder, oak etc.) are used for finishing works, carpentry, floors and in other industries for various purposes.

Wood is a natural anisotropic, resiliently plastic material. The internal structure of the wood is complex enough so that it is possible to single out the basic patterns without resorting to assumptions of various kinds. The strength and deformability of wood depends on many factors and influences. Such factors include humidity, age, imperfections, damage, wood performance under various types of load.

Some of the above factors can be eliminated using glued wood. The use of glued wood in the construction of buildings and structures is justified by high technical and technological indicators of its properties as a structural material. Due to the dispersion and removal of defects of whole wood in the volume of the layered macrostructure of glued wood, its quality is improved and strength is increased.

Nowadays, progress in various sectors of the economy allows us to test various materials and designs using modern equipment. Therefore, there was a need to determine the physico-mechanical characteristics of materials and structures with even greater accuracy and reliability until the materials reach critical and ultimate deformations, that is, to complete destruction. In 
recent years, servo-hydraulic and electromechanical presses have been developed and manufactured, and modern computer programs have been developed for them, which make it possible to test and determine most of the basic physical and mechanical properties from the beginning of material (structure) work to destruction. This means that there is the possibility of constructing real diagrams of the mechanical state (with a decreasing branch) from experimental studies. This is an urgent and promising task for researchers to use in further modern calculations building structures and various elements and parts used in other sectors of the economy. The construction and description of such deformation diagrams will make it possible to more widely and fully disclose the stress-strain state of various types of glued wood and their real work on various types of load.

Analysis of recent research and publications. A limited number of works of domestic scientists are devoted to the study of the physicomechanical properties of glued pine wood for compression along the fibers $[1 ; 2]$. We conducted such studies, modifying glued pine wood with silor [3; 4]. Most of these studies relate to the operation of glued wood under the soft test mode, that is, under the increase in loads. Therefore, after such tests on obsolete presses, we can build stress-strain diagrams " $\sigma-u$ " only to a certain point, which is much lower than the level of critical strains. This is usually associated with obsolete testing machines and related equipment for taking readings (deformations).

In recent years, electromechanical presses and servo-hydraulic testing machines have appeared, which allow testing samples with simultaneous reading of counts to failure using modern computer equipment. This allows you to build complete diagrams of $\sigma-u$ on the ascending and descending branches.

Experimental studies of solid pine wood samples of structural dimensions with uniaxial short-term load under the hard test conditions were carried out several years ago by Tuturin S.V. [5], Varenik K.A. [6]. We have conducted such studies on other species of deciduous (birch, alder, ash) and coniferous (larch, pine, spruce) wood species [7-9].

Therefore, experimental and theoretical studies of coniferous and deciduous species of glued wood for compression along the fibers in the hard test mode is an urgent task.

Statement of the problem. The purpose of the work is to conduct experimental studies of coniferous (larch, pine, spruce) and deciduous (birch, alder, ash) glued wood species for longitudinal compression under the strict test conditions. As well as the construction of complete diagrams of material deformation and determination of critical deformations, as well as the corresponding maximum stresses; establishment of the initial modulus of elasticity and cross modules.

The methodology of experimental research. For experimental studies, the following species of glued wood were selected: coniferous - larch, pine, spruce; deciduous - birch, alder, ash. Samples were made from trees that were grown in different regions of Ukraine, in particular pine, spruce, alder - in the forests of the Rivne region; birch, ash - Volyn region; larch - Ivano-Frankivsk region. Trees were picked around the age of 60 . After the cut, the trees were transported to the enterprises of the woodworking industry and were divided into logs, then cut into bars. Drying of wood blanks was carried out in special hanging chambers with a standard humidity of $12 \%$. After the bars reached standard humidity, they were sawn into boards. Then the boards were glued using resorcinol glue and sawn into samples with a cross section of $30 \times 30 \times 120$ $\mathrm{mm}$ (Fig. 1). All wood species were free from flaws and damage.

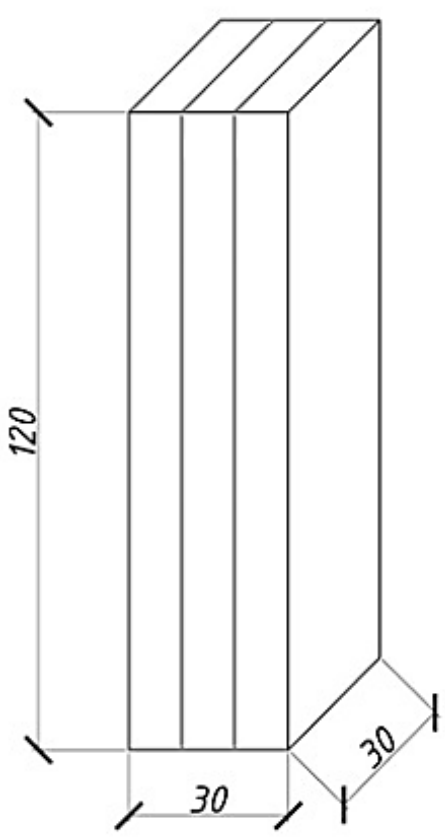

Fig. 1. The geometric dimensions of the sample

Experimental studies were carried out on a STM-100 servo-hydraulic testing machine $[10,11]$ (Fig. 2) under the hard test mode (according to the increase of displacements of the testing machine press). The interface with the software is shown in Fig. 2. The maximum load of the testing machine is 10 tons. 


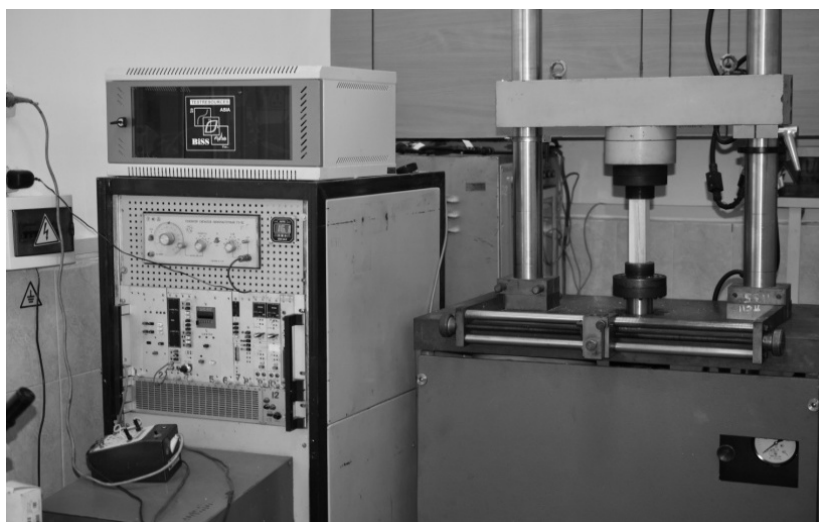

Fig. 2. Servo-hydraulic testing machine STM-100

The loading of samples was carried out and controlled using a computer and appropriate software. When testing samples, the computer interface shows the loading speed, loads with the appropriate press movement, the time of the test of the sample and other parameters (Fig. 3).

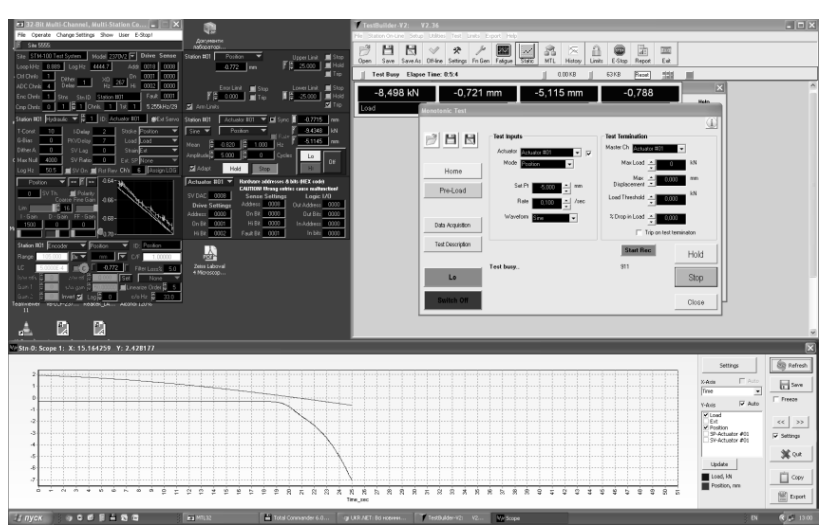

Fig. 3. Software interface

Test results. After testing the samples, the diagrams of deformation of glued wood " $\sigma-u$ " of coniferous (larch, pine, spruce) and deciduous (birch, alder, ash) wood species were constructed (Fig. 4, 5). Also, complete diagrams of deformation of glued wood with constraints at the points of ultimate deformations were constructed (Fig. 6, 7).

After a detailed analysis of the diagrams, it was found that the glued wood of all the studied species has ascending and descending branches. Also for the first time experimentally established critical deformations of glued wood and the corresponding maximum stresses.

It has been established that the strength of glued wood of all the studied species is on average $15-25 \%$ higher than solid [7-9], and the critical deformations remain almost unchanged.

According to the methods [2], diagrams $\langle\langle\mathrm{E}-\eta\rangle$ were constructed (cross modulus - stress level) of coniferous and deciduous species of glued wood (Fig. 8, 9).
The initial elastic moduli of all studied glued wood species and cross deformation moduli were determined. It was revealed that the initial elastic moduli of glued wood are larger than of solid wood.
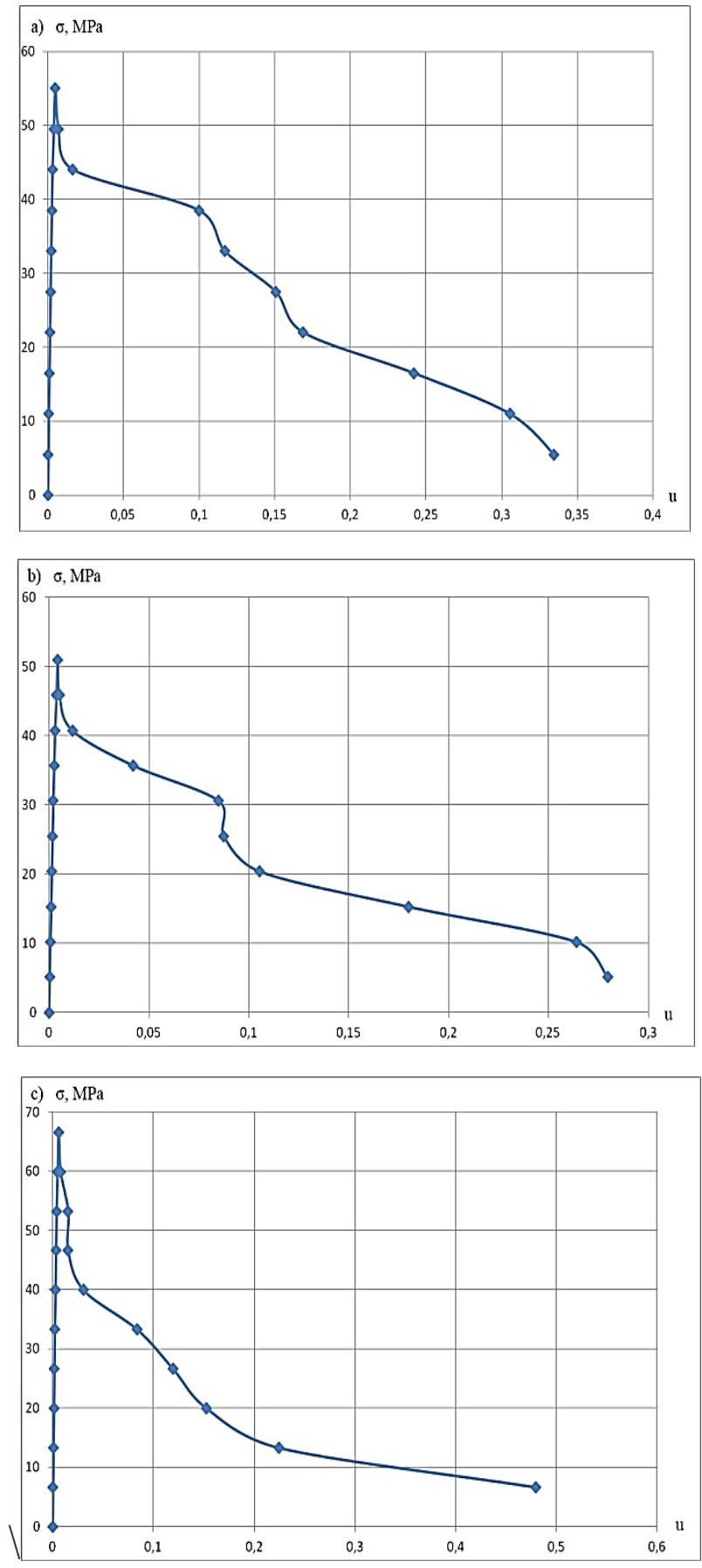

Fig. 4. Complete diagrams of deformation of glued hardwood on compression along the fibers: a) birch; b) alder; c) ash

Conclusions. 1) For the first time, experimental studies of deciduous (birch, alder, ash) and coniferous (larch, pine, spruce) glued wood species with uniaxial 

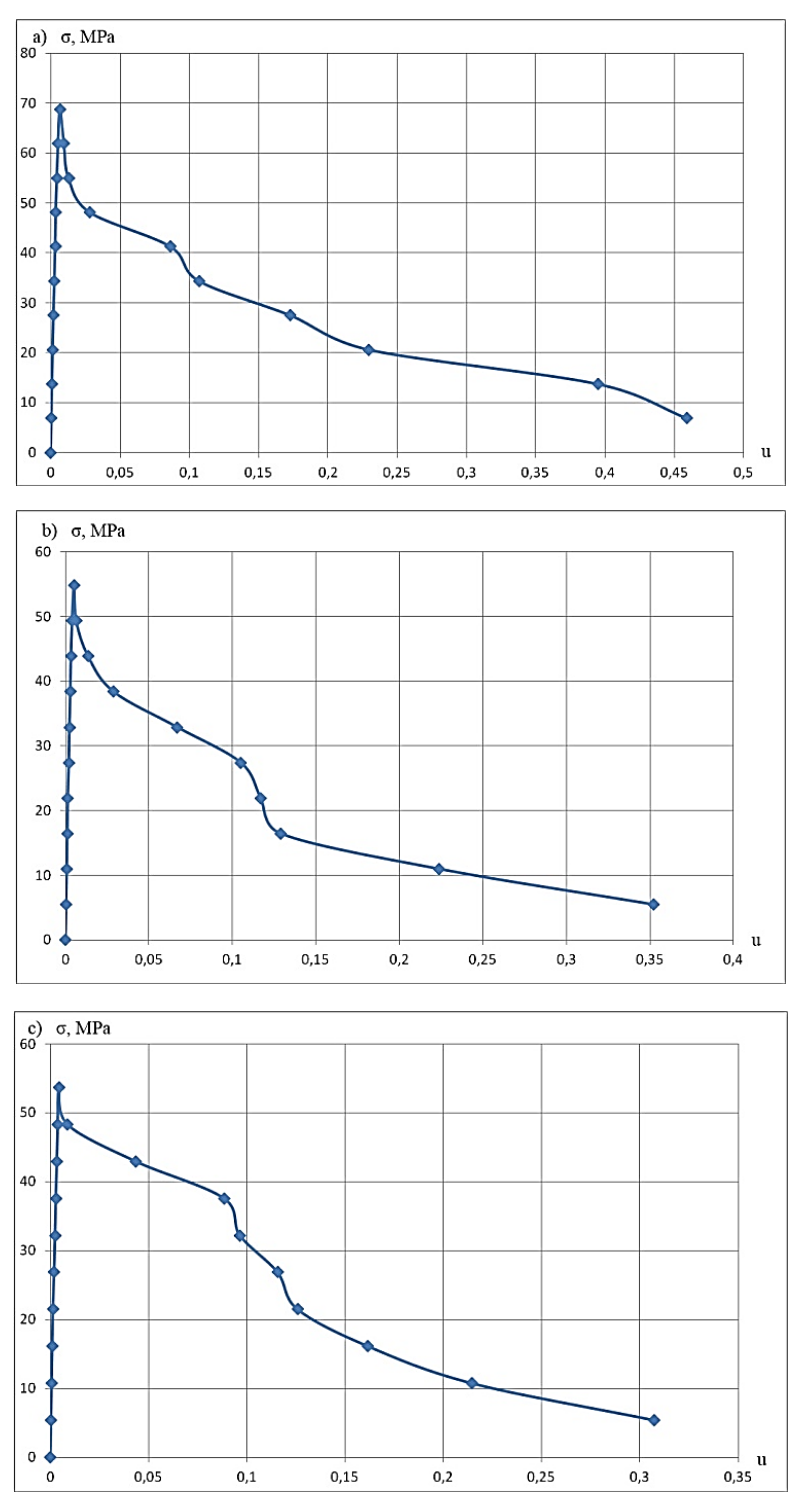

Fig. 5. Complete diagrams of deformation of glued softwood on compression along the fibers: a) larch; b) pine; c) spruce

short-term load along the fibers under the hard test mode were undertaken (by the increase in the testing machine movements).

2) Critical deformations and corresponding maximum stresses of all studied glued wood species were determined for the first time;
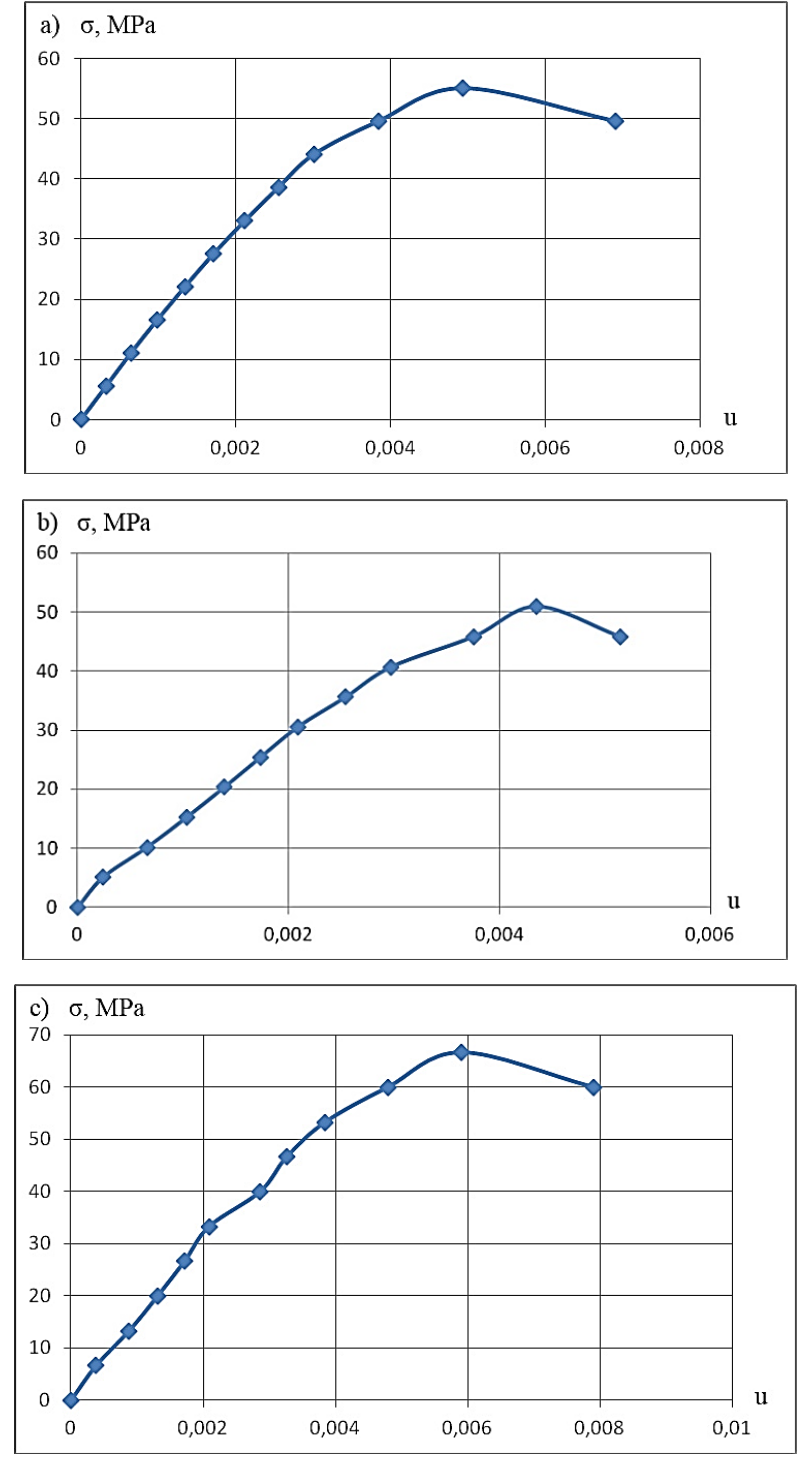

Fig. 6. Complete diagrams of deformation of glued hardwood on compression along the fibers with a restriction at the point of ultimate deformation: a) birch; b) alder; c) ash

3) It has been established that the strength of glued wood of all the studied species is on average 15-25\% higher than of solid, and the critical deformations remain almost unchanged;

4) It was revealed that the initial elastic moduli of glued wood are larger than of solid wood.

\section{References:}

1. Sasovs'kyy T.A. Napruzheno-deformovanyy stan balok iz kleyenoyi derevyny za diyi malotsyklovykh navantazhen': dys. ... kand. tekhn. nauk: 05.23.01. Rivne, 2016. 209 s.

2. Gomon S.S, Polishchuk M.V. Eksperymental'no-statystychni doslidzhennya zalezhnostey dlya tsil'noyi ta kleyenoyi derevyny. Resursoekonomni materialy, konstruktsiyi, budivli ta sporudy. Zb. nauk. prats'. Rivne: Vyd-vo NUVHP, 2018. Vyp 35. S. 60-67. 

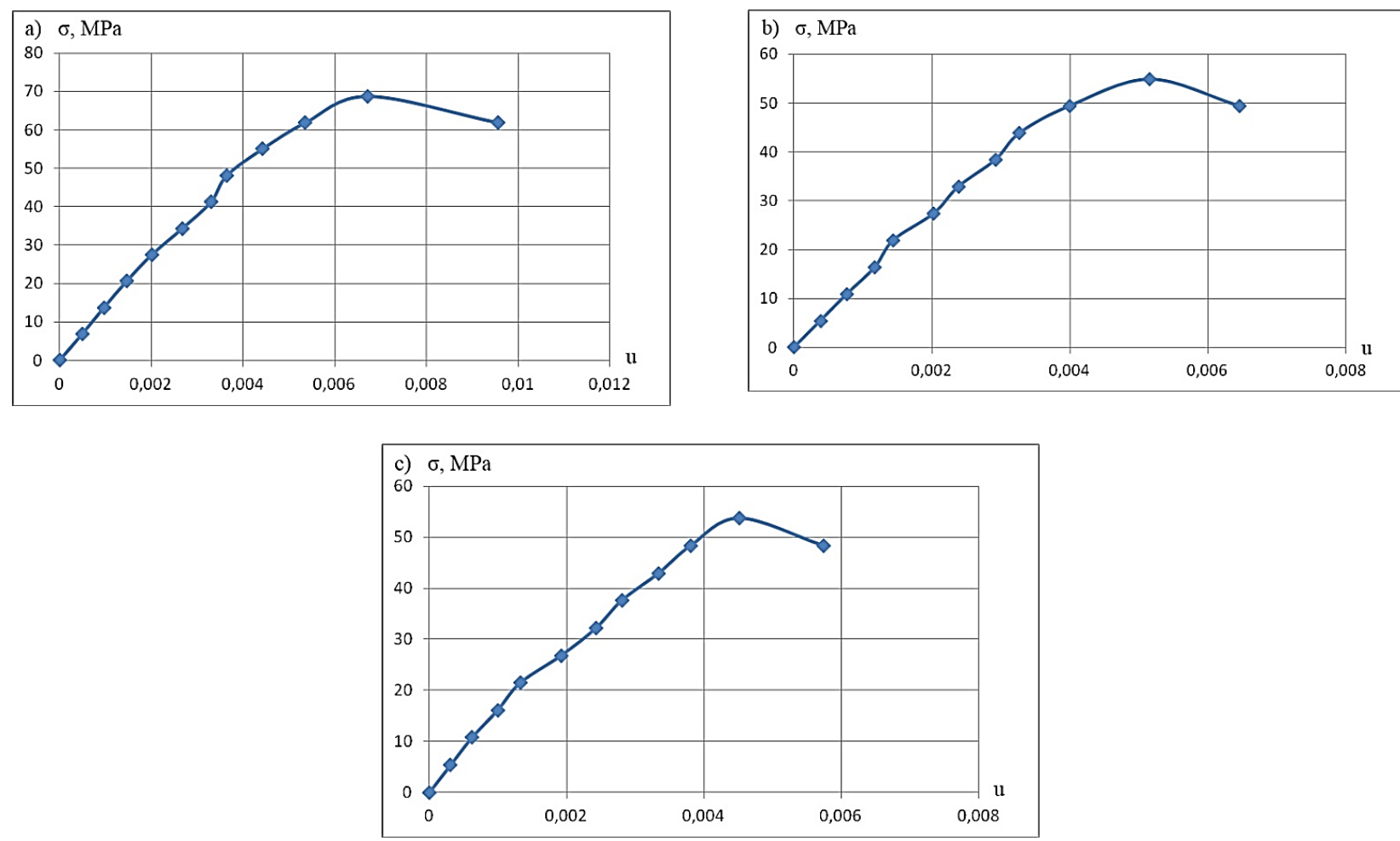

Fig. 7. Complete diagrams of deformation of glued softwood on compression along the fibers with a restriction at the point of ultimate deformation: a) larch; b) pine; c) spruce

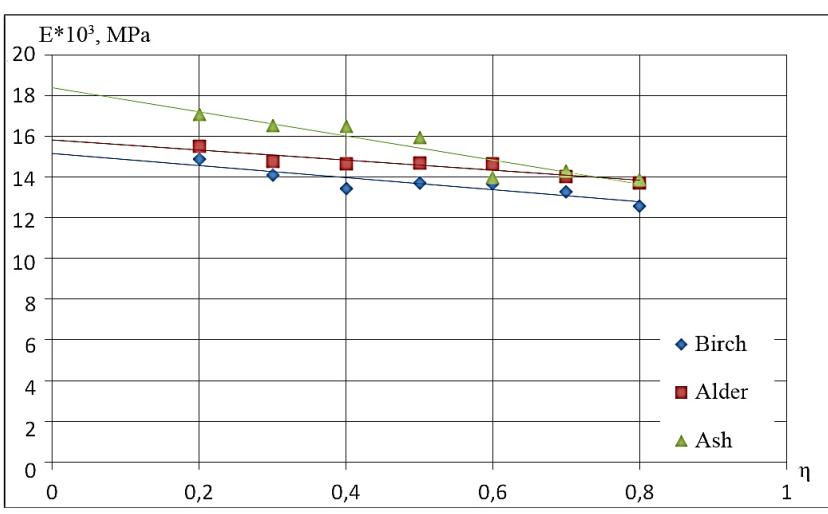

Fig. 8. Diagrams $E-\eta$ (cross modulus - stress level) of glued hardwood under uniaxial compression along the fibers

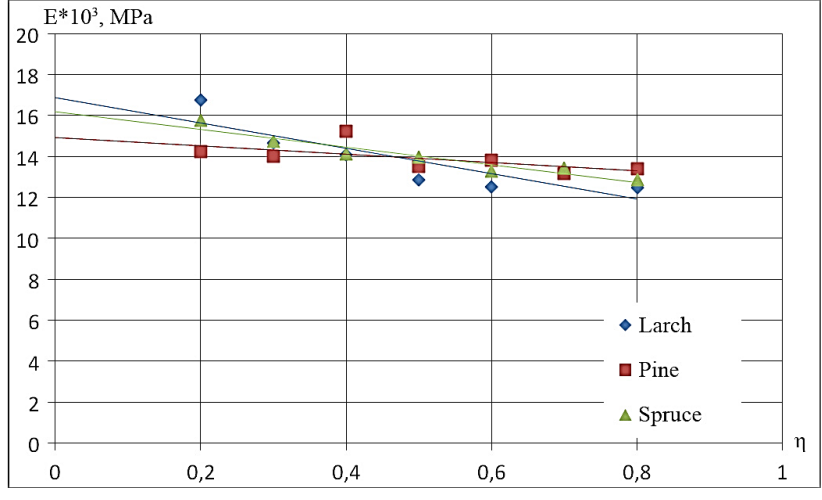

Fig. 9. Diagrams $\mathbf{E}-\eta$ (cross modulus - stress level) of glued softwood under uniaxial compression along the fibers

3. Gomon S.S., Gomon S.S., Zinchuk A.V. Doslidzhennya modyfikovanoyi sylorom kleyenoyi derevyny na stysku z vykorystannyam volokon. Vseukrayins'kyy naukovo-tekhnichnyy zhurnal "Visti Donets'koho hirnychoho instytutu”. Pokrovs'k: DVNZ «Donents'kyy NTU», 2017. № 1(40). S. 134-138.

4. Gomon S.S., Gomon S.S. Zinchuk A.V. Deformatyvnist' modyfikovanoyi sylorom kleyevoyi derevyny dlya roboty na styli z vykorystannyam volokon. Resursoekonomni materialy, konstruktsiyi, budivli ta sporudy. Rivne : NUVHP, 2017. S. 111-117.

5. Tuturin S.V. Mekhanicheskaya prochnost' drevesiny: dis. ... dokt. tekhn. nauk: 01.02.04. Moskva, 2005. $318 \mathrm{~s}$.

6. Varenik K. A. Raschet tsentral'no-szhatikh derevyannykh elementov s uchetom polzuchesti: dis. ... kand. tekhn. nauk: 05.23.01. Novgorod Velikiy : NGU im. Yaroslava Mudrogo, 2015. 167 s.

7. Gomon S.S., Gomon P.S. Pobudova diysnykh diahram mekhanichnoho stanu derevyny «б-u» sutsil'noho pererizu yalyny ta berezy za zhorstkoho rezhymu vyprobuvan'. Resursoekonomni materialy, konstruktsiyi, budivli ta sporudy. Zb. nauk. prats'. Rivne: Vyd-vo NUVHP, 2020. Vyp 38. S. 321-330. 
8. Gomon S.S., Sal'chuk V.L., Savchuk V.L., Vereshko O.V. Eksperymental'ni doslidzhennya derevyny standartnoyi volohosti za zhorstkoho rezhymu vyprobuvan'. Problemy intehrovanoho rozvytku mist: mizhnarodna naukovo-praktychna konferentsiya uchenykh ta studentiv, m. Luts'k, 29-31 sichnya 2020 r. Luts'k: LNTU, 2020. S. $18-20$.

9. Yasniy P.V., Gomon S.S. Osoblyvosti pobudovy povnoyi diahramy deformuvannya derevyny yasena za zhorstkoho rezhymu navantazhennya. Materialy Mizhnarodnoyi naukovo-praktychnoyi konferentsiyi «Fundamental'ni ta prykladni problemy suchasnykh tekhnolohiy», m. Ternopil', 14-15 travnya $2020 \mathrm{r}$. Ternopil' : TNTU, 2020. S. 52.

10. Yasniy P.V. Plastychno deformovani materialy: vtoma i trishchynotryvkist': monohrafiya. L'viv : Svit, 1998. $292 \mathrm{~s}$.

11. Yasniy P. V. et al. Microcrack initiation and growth in heat-resistant $15 \mathrm{Kh} 2 \mathrm{MFA}$ steelunder cyclic deformation // Fatigue Fract. Eng. Mater. Struct. Blackwell Science Ltd,2005. Vol. 28, № 4. P. 391-397.

\section{Гомон С.С., Піліпака Л.М. ЕКСПЕРИМЕНТАЛЬНІ ДОСЛІДЖЕННЯ МІЦНІСНИХ ТА ДЕФОРМАТИВНИХ ВЛАСТИВОСТЕЙ КЛЕЄНОЇ ДЕРЕВИНИ ЗА ЖОРСТКОГО РЕЖИМУ ВИПРОБУВАНЬ}

Проведено детальний аналіз літературних джерел вітчизняних та закордонних вчених із даної проблематики. Проанілізовано сучасне випробувальне обладнання вітчизняного та закордонного виробниитва. Розроблено методику експериментальних досліджень клеєної деревини листяних (береза, вільха, ясен) та хвойних (модрина, сосна, ялина) порід одноразовим короткочасним навантаженням вздовж волокон за жорсткого режиму випробувань на сучасних сервогідравлічних випробувальних машинах.

Вперше проведено иілеспрямовані експериментальні дослідження призм клеєної деревини конструкиійних розмірів всіх досліджуваних порід клеєної деревини одновісним короткочасним навантаженням вздовж волокон за жорсткого режиму випробувань (за приростом переміщень випробувальної машини). За результатами експериментальних досліджень побудовано повні діаграми деформування хвойних та листяних порід клеєної деревини від початку навантаження до його повного руйнування, а також повні діаграми з обмеженням в точиі граничних деформацій. Обгрунтовано, що клеєна деревина прачює на висхідній та спадній вітках. Експериментальним шляхом встановлено дійсну роботу та напруженодеформований стан клеєної деревини за одновісного навантаження вздовж волокон за жорсткого режсиму випробувань (за приростом переміщень плити випробувальної машини). Встановлено критичні деформациї всіх досліджуваних хвойних та листяних порід клеєної деревини, а також відповідні максимальні напруження. Визначено початкові модулі пружності клеєної деревини та січні модулі деформацій. Встановлено, щио міџність клеєної деревини всіх досліджуваних порід в середньому на 15-25\% більша ніж сучільної, а критичні деформачї̈ при щьому залишаються практично незмінними.

У подальшому необхідно розробити методику розрахунку згинальних та стиснутих дерев'яних конструкиій з урахуванням повної діаграми деформування суцільної та клеєної деревини.

Вказано на те, щзо в майбутньому необхідно провести експериментальні дослідження клеєної деревини, які будуть просочені різного роду хімічними елементами (мономерами чи олігомерами), для змічнення таких матеріалів.

Ключові слова: клеєна деревина, міцність, деформативність, критичні деформачї, напруження, повна діаграма деформування. 